\title{
Mycobacterium gordonae infection in freshwater fish from lakes and ponds in a park at São Paulo city, Brazil
}

\author{
Ana Maria Cristina Rebello Pinto da Fonseca Martins ${ }^{1}{ }^{*}$, Luara Lucena Cassiano ${ }^{2}$, \\ Marcia Helena Braga Catroxo ${ }^{3}$, Regina Stroebel ${ }^{4}$, Ana Paula Ruggiero-Couceiro, \\ Carlos Eduardo Campos ${ }^{6}$, Paulo César Caldas ${ }^{7}$, Jesus Ramos $^{8}$, Cristina Dib $^{9}$, \\ Eliana Roxo ${ }^{10}$, Marcio Hipolito ${ }^{11}$ \\ 1,2,3,9,10,11 Instituto Biológico de São Paulo/APTA/SAA, São Paulo, SP, Brazil. \\ ${ }^{4}$ Prefeitura Municipal de São Paulo, SP, Brazil. \\ ${ }^{5}$ Autonomous Veterinarian, São Bernardo do Campo, SP, Brazil. \\ ${ }^{6,7,8}$ Fundação Oswaldo Cruz, Rio de Janeiro, RJ, Brazil.
}

\begin{abstract}
In recent year's fish farming has greatly increased in Brazil, favoring the development of diseases such as mycobacteriosis. This is a chronic progressive disease that affects temperate and tropical fish, both freshwater and marine. Mycobacteriosis can occur in several species of fish and amphibian. In addition, some species of Mycobacterium spp. can be transmitted to humans by occupational or recreational source. A total of 54 fishes from lakes from São Paulo city, were collected and examined for mycobacteriosis. Granulomas were visualized in 5 fishes via histopathology $(H \& E)$, and acidalcohol resistant bacilli were visualized in 8 animals by electron microscopy and 8 were positives using the Fite -Faraco technique. In this study, we isolated acid-fast bacillus from one fish which were identified as M. gordonae by molecular methods: PCR and sequencing.
\end{abstract}

Keywords-mycobacteriosis, pathology, aquaculture, sanity, disease.

\section{INTRODUCTION}

In recent years fish farming has greatly increased in Brazil, favoring the development of diseases such as mycobacteriosis (ISHIKAWA et al., 2001; ROMANO et al., 2012). This is a chronic progressive disease that affects temperate and tropical fish, both freshwater and marine (JACOBS et al., 2009).

Mycobacteria spp. can cause serious and costly diseases in different vertebrates and invertebrates, such as humans (tuberculosis, leprosy, Buruli ulcer), livestock (bovine tuberculosis) and ectotherms (reptiles, amphibians and fish) (BIET et al., 2005; GRANGE \& YATES, 1986; JACOBS et al., 2009; REAVILL \& SCHMIDT, 2012; SHINNICK \& GOOD, 1994; TORTOLI, 2003; TURENNE et al., 2007).

The first Mycobacterium spp. was identified in carp in 1897 (BATAILLON, DUBARD, TERRE, 1897). This was named as Mycobacterium piscium and was shown to be highly pathogenic to frogs and some endothermic animals. The main species identified in captive and wild fishes are M. marinum, M. fortuitum and M. chelonae (mainly in marine fish). New species have also been proposed, including M. salmoniphilum. Other organisms related to M. ulcerans and the M. tuberculosis complex have also been recently implicated (GAUTHIER \& RHODES, 2009; JACOBS et al., 2009).

Transmission typically occurs by ingestion of contaminated food and water, but transovarian transmission can also occur in viviparous species (ASTROFSKY et al., 2000; GAUTHIER \& RHODES, 2009; JACOBS et al., 2009).

Granulomas are mainly located in the spleen, liver and kidney during the initial stages of the disease, but can spread to any other organs, leading to terminal illness. At the beginning of the infection, macrophages are invaded and become epithelioid cells. Giant cells may or not be present (GAUTHIER \& RHODES, 2009; JACOBS et al., 2009).

In fish, the severity of mycobacteriosis ranges from chronic infection, without major changes in tissues and few losses, to severe and acute infection, with high mortality, depending on the mycobacteria and fish species involved. Clinical signs include weight loss, apathy and lethargy, decreased fertility spine defects, exophthalmia, abnormal behavioral, changes in skin color, and ulcerative lesions in the skin, gills, fins and musculature. There may be enlargement of liver, spleen, kidney and nodular lesions in internal organs (ASTROFSKY et al., 2000; GAUTHIER \& RHODES, 2009; JACOBS et al., 2009; ROMANO et al., 2012). 
There are few reports of mycobacteriosis in fish and amphibian species in Brazil. Studies are needed to understand the occurrence and consequences of the disease in animals maintained in captivity in lakes, ponds and parks (FERREIRA et al., 2006; ISHIKAWA et al., 2001; LEITE et al., 1998; ROMANO et al., 2012).

The aim of this study was to study this disease of fishes in the lakes and ponds park in São Paulo city and from decorative lake, unfit for consumption.

\section{MATERIAL AND METHOD}

\subsection{Experimental Design}

A total of 54 fishes (41 carps, 9 tilapias, 2 curimbatas (Prochilodus lineatu)s, 2 pirapitingas (Piaractus brachypomus), both male and female, were randomly collected from lakes and pounds in Jardim da Luz, located in downtown area at São Paulo City, Brazil. Samples of spleen, hepatopancreas, kidney and gills were fixed in $10 \%$ neutral buffered formalin or frozen. The sampled fishes varied in length from $10 \mathrm{~cm}$ to $52 \mathrm{~cm}$. Macroscopically, 2 carps showed lesions suggestive of granulomas.

\subsection{H.E. Technique}

Serial sections were prepared from the fixed material: fragments embedded paraffin. $5 \mu \mathrm{m}$ sections were cut using a microtome and adhered to the glass slides and stained by hematoxylin-eosin.

\subsection{Fite- Faraco Ziehl-Neelsen technique (Z-N) (we used Fite-Faraco staining protocol, since the classic staining protocol of Ziehl Neelsen may result in false negatives).}

Serial sections were prepared from the fixed material: fragments embedded paraffin. $5 \mu \mathrm{m}$ sections were cut using a microtome and adhered to the glass slides. The sections will be de-paraffinize in a solution composed of two parts of xylol and one part of peanut oil (or almond oil) for 15 minutes. The sections are then washed in tap water to remove the remaining xylene / oil mixture. Filter on carbol fuchsin solution, DO NOT HEAT, for 20 mins. Wash in running tap water. Differentiation will be done by means of $10 \%$ sulfuric acid for 2 minutes. Wash well in running tap water, rinse distilled water. Counterstain in $0.25 \%$ methylene blue for 20 seconds. Wash and blot dry. DO NOT DEHYDRATE IN ALCOHOL. Clear in xylene. Repeat the blotting-xylene treatment until section is clear. Mount in a DPX type mountan (FITE ET AL., 1947).

\subsection{Negative Contrasting}

The samples were suspended in $0.1 \mathrm{M}$ phosphate buffer $\mathrm{pH} 7.0$ and placed in contact with metal grids previously coated with collodion and carbon film drained with filter paper. They were negatively contrasted with ammonium molybdate to $2 \%$ and pH 5.0 and observed using a Philips EM 208 (BRENNER \& HORNE, 1959; HAYAT \& MILLER, 1990) TEM.

\subsection{PCR}

For mycobacterial isolation, approximately one gram of each clinical specimen was ground with sterile sand, decontaminated by the classical Petroff method and seeded in four tubes containing medium of Stonebrink and four tubes with Petragnani medium. Two tubes of each seeded medium were incubated at $37^{\circ} \mathrm{C}$ and the remaining tubes at room temperature. All tubes were observed weekly for checking the growth of the colonies (KANTOR, 1988). To PCR, the isolated colonies were resuspended in $1.5 \mathrm{~mL}$ sterile ultrapure water. DNA extraction was performed by inactivation of the samples by boiling at $100^{\circ} \mathrm{C}$ for 5 minutes, after which they were subjected to freezing at $-20^{\circ} \mathrm{C}$ for at least one hour (BEMER-MELCHIOR \& DRUGEON, 1999).

Thawed samples were PCR amplified using TB11-TB12 primers, designed for identification of the Mycobacterium genus (TELENTI et al., 1993). These generated a final product of 439 bases pairs. DNA amplifications were held in thermal cycler, submitting samples to the initial treatment of $95^{\circ} \mathrm{C}$ for 5 minutes, followed by 45 cycles of three temperatures: denaturation at $94^{\circ} \mathrm{C}$ for 1 minute, annealing at $65^{\circ} \mathrm{C}$ for 1 minute and extension at $72^{\circ} \mathrm{C}$ for 1 minute. After the last cycle, was held a final extension at $72^{\circ} \mathrm{C}$ for 7 minutes after which the product remained at $4{ }^{\circ} \mathrm{C}$ until its analysis by electrophoresis in horizontal vat. PCR products were observed in $1.5 \%$ agarose gel containing $0.01 \%$ ethidium bromide, viewed under UV light and photographed with the aid of molecular gel doc system. To sequencing, the almost sequences of the 16S rDNA gene were obtained as described by CAMPOS et al. (2012). 


\section{RESULTS AND DISCUSSION}

Of the 54 fishes examined, 8 were positives when stained using the Fite -Faraco Z-N technique (Fig 1). In the H\&E staining, 5 animals presented numerous granulomas (Fig 2 a and b) of numerous sizes, with caseous necrosis in the center, eosinophilic cells and surrounded by inflammatory cells and fibroblasts ( 1 animal in the spleen, 3 kidneys and pancreas, 1 in hepatopancreas).

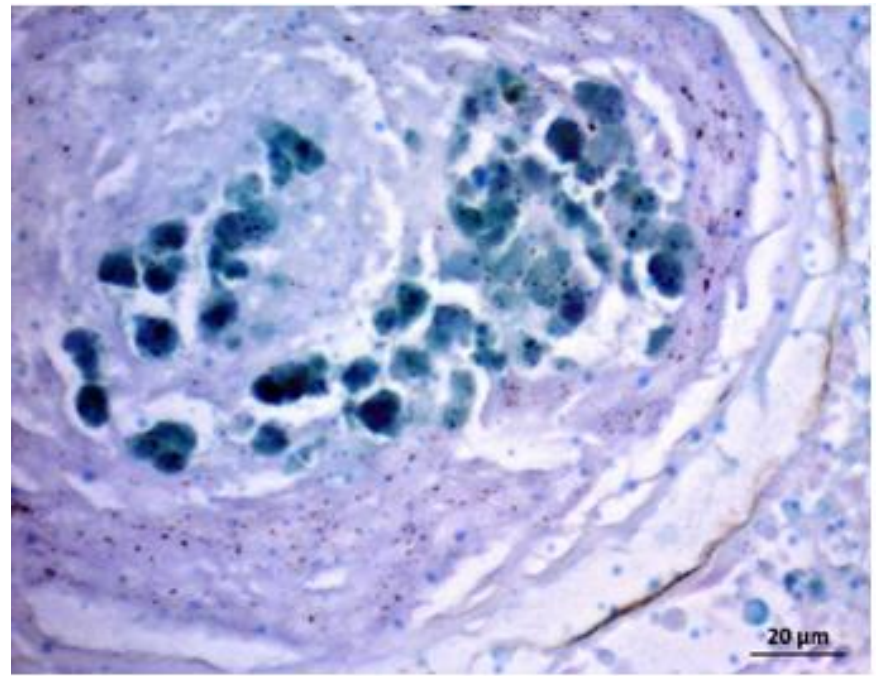

FIG 1 - PHOTOMICROGRAPH OF HEPATOPANCREAS SHOWING NUMEROUS RED MYCOBACTERIA (SMALL

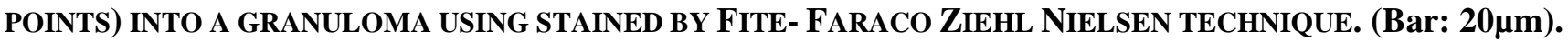
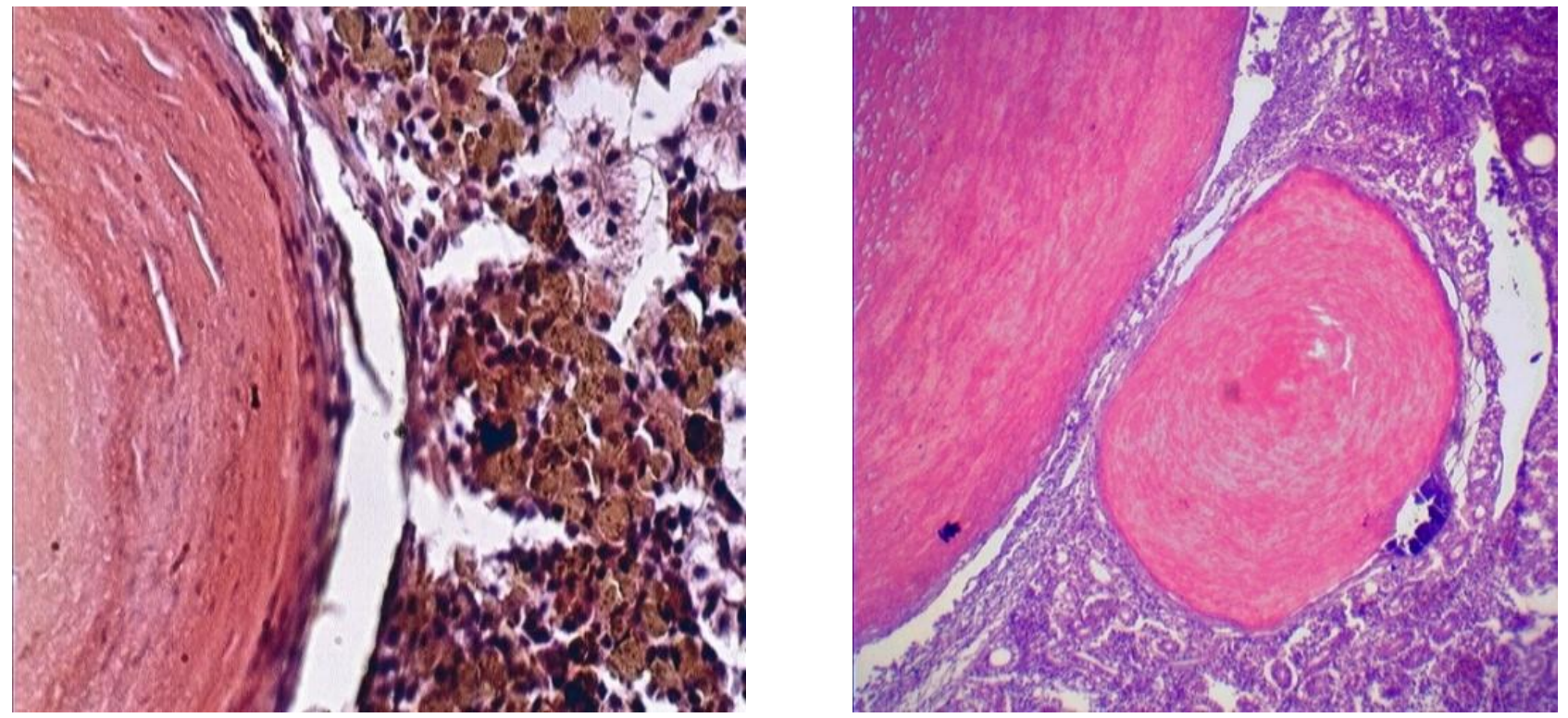

FIG 2 a and $b$ - PHOTOMICROGRAPH SHOWING AT RIGHT 2 GRANULOMAS WITH CASEOUS NECROSIS IN THE CENTER, SURROUNDED BY EOSINOPHILIC AND FIBROBLASTS AND INFLAMMATORY CELLS (LYMPHOCYTES, NEUTROPHILS, HETEROPHILES AND MELANOMACROPHAGES) AND AN AREA OF CALCIFICATION (ARROW).

HE. BAR $=200 \mu \mathrm{m}$. ON THE LEFT, AT HIGHER MAGNIFICATIONS, A GRANULOMA AND NUMEROUS MELANOMACROPHAGES (BROWN). HE. (Bar: $50 \mu \mathrm{m})$.

It was observed, thus, lymphocytes, neutrophils and heterophiles. Some macrophages alone or in groups, were filled with golden-yellow substance (melanomacrophage) next to the granulomatous or degenerative lesions. The most severe changes were observed in the kidney that showed convoluted tubules in vacuolar degeneration or necrosis. Glomeruli were also visualized in degenerating, necrotic or deformed, hypo- or hyperplastic and presenting increased Bowman's space. Nephrocalcinosis was observed in 2 cases.

With the transmission electron microscope, Mycobacterium spp was also observed (Fig 3 a and b) in 8 fishes, these same animals that were positive for the $\mathrm{Z}-\mathrm{N}$ technique. 


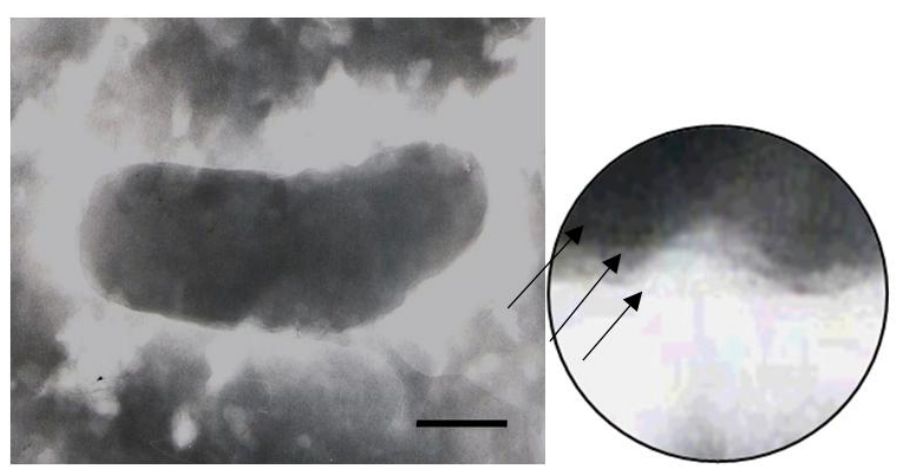

\section{FIG 3 a and b - ELECTRON MICROGRAPH OF MYCOBACTERIUM SPP IN FISH LIVER AND VISUALIZED BY NEGATIVE STAINING TECHNIQUE. AT THE ARROWS, THE TRIPLE LAYER ENVELOPE. (Bar: 140 nm)}

Slow-growing scotochromogenic colonies were obtained from one fish (Fig 4). These colonies were catalase positive and did not reduce nitrate. The nearly entire $16 \mathrm{~S}$ rDNA gene $(1456 \mathrm{pb})$ sequence obtained showed $99.65 \%$ identity with $M$. gordonae type strain (ATCC 14470). This was deposited in GenBank (accession number JN899581). We also sequenced the 16S rDNA gene of the type strain of M. gordonae ATCC 14470, (accession number JN899579) for comparative identification purposes, as in the sequence GenBank (X52923) had 8 unidentified (N) bases.

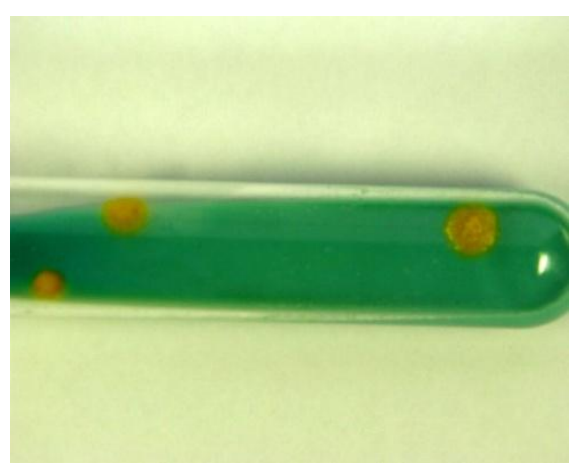

\section{Fig 4 - COLONIES OF MYCOBACTERIUM GORDONAE ISOLATED FROM FISH IN PETRAGNANI MEDIUM}

\section{DISCUSSION AND CONCLUSION}

Brazil has enormous potential for animal and fish farming production, given its vast land, water sources and favorable weather conditions. In Brazil, fish are typically raised in lakes for consumption, although in this study they were not intended for consumption.

High concentrations of fish can favor the onset epizootic disease outbreaks caused by Mycobacteria spp, although in natural environmental conditions spontaneous disease outbreaks can also occur (GAUTHIER \& RHODES, 2009; HECKERT et al., 2001; RAMSAY et al., 2009).

Mycobacteriosis can occur in several species of fish. In addition, some species of Mycobacterium spp. can be transmitted to humans by occupational or recreational source (BHATTY et al., 2000; GAUTHIER \& RHODES, 2009; JACOBS et al., 2009; REAVILL \& SCHMIDT, 2012).

In Brazil, there are a few studies on mycobacteriosis in ectotherms. MOK and CARVALHO in 1984, described the presence of M. chelonei in Bufus marinus and B. granulosus, and although mycobacteriosis outbreaks in frog farms have been reported by FERREIRA et al., 2006. In fish, was notification by ISHIKAWA et al., 2001 and ROMANO et al., 2012.

Histopathological examinations are important for early diagnosis of mycobacterial infection in fish. Granulomas are suggestive of mycobacteriosis but are not pathognomonic of the disease; acid-fast bacilli must be visualized in the lesions. A positive culture will provide a definitive diagnosis, but it is not very easy to isolate mycobacterias at $37^{\circ} \mathrm{C}$, the optimum temperature for human pathogens. Fishes isolate are well-characterized by molecular methods.

In this study, we isolated acid-fast bacillus from one fish which were identified as M. gordonae by molecular methods. It is recommended that further, more in-depth, studies are undertaken to gain a better insight of the impact of this disease in cultured and wild fish species in Brazil. 


\section{ACKNOWLEDGEMENTS}

The authors want to Thanks FAPESP

\section{REFERENCES}

[1] A. Telenti, F. Marchesi, M. Balz, F. Bally, E.C. Bottger, T. Bodmer. Rapid identification of mycobacteria to the species level by polymerase chain reaction and restriction enzyme analysis. Journal of Clinical Microbiology 31(2), 175-178. 1993.

[2] C.E. Campos, P.C. Caldas, H. Ohnishi, T. Watanabe, K. Ohtsuka, S. Matsushima, N.V. Ferreira, M.V. Silva, P. Render, L.D. Carvalho, R.F. Medeiros, A.B.B.U.D. Filho, F.C. Montes, T.C. Galvão, J.P. Ramos. First isolation of Mycobacterium kyorinense from clinical specimens in Brazil. Journal of Clinical Microbiology 50 (7), 2477-2478, 2012.

[3] C.M. Ishikwa, E.R. Matushima, C.W.O. Souza, J. Timenetsky, M.J. Ranzani-Paiva. Micobacteriose em peixes. Boletim do Instituto de Pesca 27, 231-242, 2001.

[4] C.Q.F. Leite, C.W.O. Souza, S.R. Leite. Identification of Mycobacteria by Thin Layer Chromatographic Analysis of Mycolic Acids and Conventional Biochemical Method: Four Years of Experience. Memórias do Instituto Oswaldo Cruz 93(6), 801-805, 1988.

[5] C.Y. Turenne, R. Wallace, M.A. Behr. Mycobacterium avium in the Postgenomic Era. Clinical Microbiology Reviews 20(2), 205229, 2007.

[6] D.R. Reavill, R.E. Schmidt. Mycobacterial lesions in fish, amphibians, reptiles, rodents, lagomorphs, and ferrets with reference to animal models. The Veterinary Clinics of North America: Exotic Animal Practice 15(1), 25-40, 2012.

[7] D.T. Gauthier, M.W. Rhodes. Mycobacteriosis in fishes: A review. The Veterinary Journal 180(1), 33-47, 2009.

[8] E. Bataillon, L. Dubard, L. Terre. Un nouveau type de tuberculose. Comptes rendus des Séances de la Sociéte’ de Biologie 49, 446449, 1987.

[9] E. Tortoli. Impact of Genotypic Studies on Mycobacterial Taxonomy: the New Mycobacteria of the 1990s. Clinical Microbiology Reviews 16(2), 319-354, 2003.

[10] F. Bier, M.L. Boschiroli, M.F. Thorel, L.A. Guilloteau. Zoonotic aspects of Mycobacterium bovis and Mycobacterium aviumintracellulare complex (MAC). Veterinary research 36(3), 411-436, 2005.

[11] G.L. Fite, F.J. Cambre, M.H. Turner. Procedures for demonstrating lepra bacilli in paraffin sections. Archives of Pathology, V43, p624-625, 1947.

[12] I.N. Kantor. Bacteriologia de la tuberculosis humana y animal. Serie de Monografías científicas Y Técnicas. Rev.1ed. Buenos Aires: Centro Panamericano de Zoonosis, 1998.

[13] J.M. Grange, M.D. Yates. Infections caused by opportunist mycobacteria: a review. Journal of the Royal Society of Medicine 79(4), 226-229, 1986.

[14] J.M. Jacobs, C.B. Stine, A.M. Baya, M.L. Kent. A review of mycobacteriosis in marine fish. Journal of Fish Diseases 32(2),119-130, 2009.

[15] J.M. Ramsay, V. Watral, C.B. Schreck, M.L. Kent. Husbandry stress exacerbates mycobacterial infections in adult zebrafish, Danio rerio (Hamilton). Journal of Fish Diseases 32(11), 931-941, 2009.

[16] K.M. Astrofsky, M.D. Schrenzel, R.A. Bullis, R.M. Smolowitz, J.G. Fox. (2000). Diagnosis and management of atypical Mycobacterium spp. infections in established laboratory zebrafish (Brachydanio rerio) facilities. Comparative Medicine 50(6), 666 $672,2000$.

[17] L.A. Romano, L.A. Sampaio, M.B. Tesser. Micobacteriosis by Mycobacterium marinum in Brazilian flounder Paralichthys orbignyanus and barber goby Elacatinus figaro: histopathological and imunohistochemical diagnosis. Pesquisa Veterinária Brasileira 32(3), 254-258, 2012.

[18] M.A. Bhatty, D.P.J. Turner, S.T. Chamberlain. Mycobacterium marinum hand infection: case reports and review of literature. British Journal of Plastic Surgery 53(2), 161-165, 2000.

[19] M.A. Hayat, S.E. Miller. Negative Staining. Mc. Graw-Hill Publ. Company. 253 p. 1990.

[20] P. Bemer-Melchior, H.B. Drugeon. Inactivation of Mycobacterium tuberculosis for DNA Typing Analysis. Journal of Clinical Microbiology 37(7), 2350-2351, 1999.

[21] R. Ferreira, L.S. Fonseca, A.M. Afonso, M.G. Silva, M.H. Saad, W. Lilenbaun. A report of mycobacteriosis caused by Mycobacterium marinum in bullfrogs (Rana catesbeiana). The Veterinary Journal 171(1), 177-180, 2006.

[22] R.A. Heckert, R.A. Eckert, S. Elankumaran, A. Milani, A. Baya. Detection of a New Mycobacterium Species in Wild Striped Bass in the Chesapeake Bay. Journal of Clinical Microbiology 39(2), 710-715, 2001.

[23] S. Brenner, R.W. Horne. A negative staining method for high resolution electron microscopy of viruses. Biochimica et Biophysica Acta 34, 103, 1959.

[24] T.M. Shinnick, R.C. Good. Mycobacterial taxonomy. European Journal of Clinical Microbiology \& Infectious Diseases 13(11), 884901, 1994.

[25] W.Y. Mok, M. Carvalho. Ocuurence and experimental infection of toads (Bufo marinus and B. granulosus) with Mycobacterium chelonei subs. abcessus. Medical Microbiology 18, 327-333, 1984. 